\title{
Wastage of Girl-Child in Sub-Saharan Africa: Implications for Educational Planners
}

\author{
Dr. Adebayo, Florence Aduke
}

\author{
Department of Educational Foundations and Management, Faculty of Education, Ekiti State University, Ado-Ekiti, Nigeria
}

dukesseyi2000@gmail.com

\section{Doi:10.5901/mjss.2015.v6n3s1p471}

\begin{abstract}
Wastage to this paper means people whose lives depend on variables that are detrimental to their progresses and contributions to nation building. In sub-Saharan Africa, the researcher observed that the ways girl-child is been wasted through abduction, child-trafficking, prostitution, early marriage, hostages, impregnation, drug abuse, baby factory, drop-outs is alarming and perhaps may affect the life of the girl-child. Hence, there is the need for the society and most importantly educational planners to address this issue. Therefore, the researcher through observations, interview and social media delved into the meanings, causes, effects, solutions of these social menaces most importantly abduction, baby factory and trafficking that have eaten deep into the life of the girl-child. Its implication to the educational planners such as strategic plan, curriculum review, capacity building, Networking and collaboration were identified. It was recommended that government should enact stringent law against the penetrators, Security measures should be intensified at the boarders and law enforcement agencies should be giving capacity building about baby factories and its correlation with human trafficking. The paper concluded that education Stakeholders (parents, schools, government, educational planners, the child, society, law enforcement agencies) should be ready to assist, create awareness and help the girl-child out of these cankerworms that prevails in our society.
\end{abstract}

Keywords: wastage, girl-child, educational planner, abduction, baby factory and child trafficking.

\section{Introduction}

It is pertinent to note that education is the bedrock on which other developmental processes revolve. Education is the life wire or life blood of an individual or any organisation development. It is the most potent instrument for development and for mental and social emancipation. Adebayo (2012) stated that education transforms and builds in individual an inherent capacity to acquire appropriate information, skills and competence for survival in any given society. Implicit in this is that education is the framework upon which development and continuity of society hinges. Hence, it is the responsibility of the government, most importantly in sub-Saharan African countries to be up to the task of educating all citizens. This is because people who are not educated may not be able to contribute significantly in the task of national building and development.

Most sub-Saharan African countries, especially Nigeria in the national policy on education indicated free and compulsory Universal Basic Education (FGN, 2004). In Nigeria, despite its free education policy at primary and junior secondary school (JSS) levels, access to education for all remains unattainable more so for female children and women. This could be attributed to the challenges facing the girl-child through parental factors such as socio-economic, trafficking, religious beliefs, culture, fear of mixing up with the opposite sex and lack of time to care for the girl - child. Societal factors such as baby factory venture, abduction, kidnapping, rape, poverty, drug abuse, unemployment and gender disparity. Government factors such as drop-out, out of school and poor funding of schools and religious factor such as religious beliefs, culture and no education for the girl-child. Fasola (2014) supported these factors when he stated that adolescent pregnancy is not only a health issue. It is deeply rooted in poverty, gender inequality, violence, force marriage, power imbalances between adolescent-girls and their male partners, lack of education and the failure of systems and institutions to protect the rights of the girl-child. He emphasised the need to invest in adolescent girls to enable them have the opportunity to reach their full potentials and claim their rights. Therefore, educating the people at the grassroots on the consequences of baby factory, child trafficking, and abduction could enhance its reduction in the society.

A hang-on-approach could be adopted by the parents and teachers for improved efficiency and effectiveness of bailing the girl-child out of the challenges being faced. Hence, the girl - child would benefit from this by having a sense of belonging and have somebody to lean on and trust for survival. Human trafficking is ranked the third most common crime after economic fraud and drug trafficking in Nigeria according to UNESCO. UNESCO (2003) statistics showed low school 
attendance by female out of 7.3 million children out of primary school about $62 \%$ were female in sub-Saharan Africa. Therefore wastage in education describes the failure of the school system to achieve its set objectives for instance, spending extra time to graduate a cohort of students. It could also be a failure to achieve a hundred percent progression rate of students from one grade level. Anyanwu (2013) posited that wastage manifests in a school system if the students input years exceed their output years. To this paper, it seems the problem of wastage arises in sub-Saharan African countries as a result of high out-of-school, drop-out, abduction, child trafficking, kidnapping, baby factory, poverty, unemployment, among others.

It was observed that due to poverty level of some parents, they engage their girl-child in street hawking, petty trading, baby-sitting, domestic activities, house girls, baby production for economic reasons. Also, due to unemployment syndrome, some youths become kidnappers and do kidnap the girls for sale to prostitution or baby factory to bear children that would be sold for exchange of cash. During war, terror attack or political upheaval, for example Central African Republic, Kenya, Sierra Leone, Liberia and Nigeria girls are raped and disenchanted which inflicted life phobic of men into their minds or set fear of cannot make it again. It is worthy to note that the same government that has invested a huge amount of resources (human and non-human) to increase the supply of education allows any child who wants to drop out of school to do so at will. These drop-outs engage in various anti-social activities (drug abuse, kidnapping) that are detrimental to life. Adebayo (2007) stated that man is born free but the society put him in chains. Implicit in this, is that the society contributed to the wastage of the girl-child in the areas of gender disparity, early marriage, rape, abduction, poverty, child trafficking, baby factory among others. These deterred the girl-child to meet up with the challenges ahead of her and make her useless to herself and the society at large.

Since the problem of this study emanated from the observed challenges facing the girl-child in sub-Saharan Africa and it seems the Government with the assistance of educational planners and the parents are not paying attention as expected to assist the girl-child. No girl-child wants to be identified with these social challenges because of the stigmatisation in our society hence, the paper examine some wastage areas of the girl-child, causes, its effects, proffer solutions and its implication for educational managers. The methods adopted by the researcher are social media, interview observation, and personal contact with some of the affected girls to identify the most common challenges faced by these girls in our society. Based on the information gathered, the paper delved into the areas of abduction, baby factory and child trafficking.

\section{Abduction}

Child abduction or child theft is the unauthorized removal of a child under the age of legal - adulthood from the custody of the child's natural parents or legally appointed guardians. The abduction could be by parental child abduction that is unauthorised custody of a child without parental agreement which removes the child from care, access and contact of the parents. Abduction could also be by strangers from outside the family who steal a child for criminal purposes which may include: extortion, to elicit a ransom from the guardians for the child's return, illegal adoption, for human trafficking, to exploit the child themselves or by trade in a list of possible abuses including slavery, forced labour, sexual abuse, or even illegal organ trading murder.

In pre-colonial Africa, large-scale abductions of girls occurred in the course of the trans-Atlantic slave trade in the fifteenth through nineteenth centuries in West Africa, and in the eastern and central African Arab-Swahili slave trade, which peaked in the nineteenth century. In both cases, girls were sold into slavery to lands beyond the continent. Abducted girls serve as domestics, porters, messengers, and general camp-followers. Girls, some as young as ten, become sex slaves for the abductors. While internal pre-colonial abductions sought to integrate their victims into the captors' society, modern abductions seek to isolate, separate, brutalize, and intimidate the children into malleable errands. In addition, abducted girls are been forced to commit rape, tortured, and killed. During the last four decades of the twentieth century, the most notorious and widespread abductions of children in Africa have been closely associated with armed conflict in such countries as Angola, Burundi, the Democratic Republic of Congo (formerly Zaire), Mozambique, Rwanda, Somalia, Sudan, Sierra Leone, and Uganda and currently in Nigeria.

There are reports that abduction of children to be used or sold as slaves is common in parts of Africa. The Lord's Resistance Army, a rebel paramilitary group operating mainly in northern Uganda, is notorious for its abductions of children for use as child soldiers or sex slaves. According to the Sudan Tribune, as of 2005, more than 30,000 children have been kidnapped by the LRA and their leader, Joseph Kony. In Nigeria, nearly 267 Nigerian schoolgirls were kidnapped from their boarding school in Chibok by the Islamist militant group Boko Haram. They are suspected to be deep in Nigeria's North-Eastern, Sambisa Forest. Many fear that at least some of the girls may have been dispersed to neighbouring Chad and Cameroon, either to other militants or into the global marketplace of children destined for every 
manner of work, from domestic or agricultural labour to sexual exploitation, forced begging, and child soldiering. The smiling Boko Haram leader, Abubakar Shekau, in a video said, "I abducted your girls, I will sell them in the market, by Allah" There is a market for selling humans.

Many of the abductors engage the girls in so many acts such as; Sex slave, Domestic slaves, Prostitution, Baby factory, Rituals, sold to generate income, and used as an instrument of crime such as robbery.

\section{Baby Factory/Baby Harvesting}

A baby factory is a location where women are encouraged or forced to become pregnant and give up their new-borns for sale. It is also refer to as harvesting homes and this seems to be a crime against humanity. Babies produced in this circumstance miss paternal and maternal cares of the biological parents. Foundations who claim to be NGO, social welfare homes, clinics, orphanages, water bottling were baby factories as reports by the media and police in some African countries. Baby factories are operated by well organised criminal syndicates. They hired scouts to look for vulnerable girls giving them false promises of jobs or safe abortion. They hired doctors who refer pregnant girls to their clinics. The owners of baby factories networks are widely spread all over the world. Baby factory system is a shocking issue when someone is hearing it for the first time. It is an issue that brings about a great heartbreak to the minds of the people. It is an issue that brings about so many questions to the mind of the recipient. These questions among others include the following: what is the meaning of baby factory? What does it involve? Is it where they use machines to produce babies? How do they operate? According to the latest Trafficking in Persons Report of the U.S. Department of State, Africa continues to be a source, transit, and destination country for victims of different forms of forced labour and sex trafficking. Though the Report mentions sex trafficking, forced prostitution, domestic servitude, begging, forced labour in street vending, agriculture and mining as the types of human trafficking but yet to identify baby factories or baby harvesting.

\section{Child Trafficking}

The quest for material wealth at all cost has introduced a new dimension of wealth creation into the psyche of SubSaharan Africa (Nigeria, Uganda, Kenya) which is child trafficking. Child trafficking is the third largest criminal activity in the world after arms and drug trafficking (UNICEF 2006) Child trafficking is the recruitment, transportation, transfer, harbouring or receipt of persons, by means of threat or use of force or other forms of coercion, abduction of children without their consent (UN convention against transitional organised crime2000). Research evidence shows that children are trafficked for the purpose of domestic services, prostitution and other forms of exploitative labour (UNICEF, 2006). Most research, such as studies done by UNICEF, suggests that boys are much more likely than girls to be trafficked for the purposes of begging, agricultural work, experts presume this is because there is a greater female presence in trafficking for the purposes of sexual exploitation. Trafficking violates a child's right to grow up in a family environment and thus, exposes him/her to a lot of danger including violence and abuse. Children and their families are often lured by the false promise of a lucrative employment and prosperous life while others are kidnapped and sold. Children and women are recruited with promises of well-paid jobs in urban centres within the country or abroad, realizing too late that they have been lured into a debt bond. Violence, coercion and deception are used to take victims away from their families. Regretfully, Sub- Saharan Africa is a source, transit and destination country for trafficked women and children. Prostitution, domestic and exploitative labour continues to fuel this modern form of slavery.

\section{Causes of Abduction, Baby Factory and Trafficking}

\subsection{Social Reasons}

i. Poverty: A state whereby there is abject poverty in the life of a girl, in which she cannot feed and cater for herself and facing different reproach in the society, she may be forced or pushed to get involved in any of these activities in order to make ends-meet.

ii. Unemployment: Society that has a high level of unemployment will surely be experiencing different types of social problems. The jobless citizens can be lured into illegal business such as baby factory.

iii. Stigma against proper sex education for teenagers: Many parents always ignore teaching their children sex education even at teenage period. These children can easily be lured into having sex, unwanted pregnancy as well as giving birth to babies at the baby factory. 
iv. School environment: Non conducive school environment, drop-out rates, low levels of education and literacy and corruptions.

Lack of enough information on human trafficking and "baby factory" operations and inadequate funding for schools and colleges.

\subsection{Economics reasons}

Greed and love for money on the part of some of the involved citizens and ransom from the child's parents.

\subsection{Political reasons}

It has been reported that many children are abducted for slavery. A rebel group, Lord's Resistance Army is known for kidnapping children for using them as sex slaves or child soldiers.

\section{Effects of Abduction, Baby Factory and Trafficking}

\subsection{Psychological effects}

It impaired memory and concentration; confusion and disorientation (cognitive). It can also lead to shock, fear, anxiety, helplessness, hopelessness, anger, frustration and depression (affective). Withdrawal, irritability, anger, avoidance of reminders of the event (social). Poor health conditions due to a lack of the basics of healthy living, such as a nutritious diet, warmth, exercise, fresh air and sleep (physical). Traumatized because they are forced to do what they have never done in their life. Even in the process of child bearing, majority of these girls have damaged wombs. And some will not find a reasonable man to marry her even after being rescued. As a result of these, most decided to give up and commit suicides.

\subsection{Social effects}

Education will experience low enrolment rate due to withdrawal and non-registration of children by the parents and guardians. Discouraging the partnership and relationship of Africa countries and other foreign countries and investors: Foreign countries and investors are discouraged to invest, resides or have any other affair with the countries involved in the saga because of the fear of having their daughters being kidnapped or getting involved in the corrupted practices. For example, on Wednesday, 30th of April, 2014, the Denmark government banned Nigeria adoptions after raid on suspected baby factory in Lagos by the Lagos state police command. Creating distrusts for other NGOs programmes since these so called baby factories are known to be non-governmental organizations, they will render a certain level of distrust in the mind of the citizens on other NGOs especially the ones dealing with children issues.

\subsection{Economics effects}

The expenditure of the nations will be increased because of the provision of a more beefed security and other human resources. Generally, the schools will experience low internal efficiency because of the psychological effect on both students and teachers.

\section{Strategies for Possible Solutions}

i. Good parenting: Practice a secret code word with the children. Choosing a word that would not be easy for a stranger to guess. Use this code word when another adult is required to transport your child. Teach your kids about the common lures use by abductors such as for directions. The family should re-examine its role and responsibility as a socialising and nurturing agent because the family is one of the powerful social change and social support that could influence the girl-child. Support for parents through education via ante-natal and postnatal clinics, i.e. creating awareness for the mothers on these vices.

ii. Government: Government should adopt Buffalo Human Rights Law Review that advocated the use of three Ps: protection, prosecution, and prevention. Protection starts with enforcing strict measures on the matters of these vices. For many nations the first step is the criminalisation of abduction and trafficking. Prosecution 
should be instituted in the form of greater legal ramifications for traffickers, abductors and baby harvesters with punishment focused on the exploiter rather than the exploited. Employment generation. The government proposal for e-curriculum for easy accessibility by secondary schools students is a welcome policy but should be external to higher education. Collaboration: Artisan involvement in practical oriented causes, entrepreneurship skill acquisition programme in the university curriculum should be fully implemented. No acquisition, no certificate. In the Curriculum abduction, trafficking and baby factory prevention education should be introduced.

Sensitisation of countries on the issue of this cankerworm baby factory that is gradually mature to eat up the girl-child. All the sub-Saharan countries should enact serious law against baby factory. The Beijing recommendation of affirmative $35 \%$ of women in power seems to be a welcome idea, but the issue of wastage of girl-child should be looked into to have future young, middle age women occupying the positions. Support for parents through education via ante-natal and post-natal clinics, i.e. creating awareness for the mothers on these vices. Inclusion of sex education and security in the primary school curriculum. Schools to work with the department of justice to implement education programmes designed to inform students about these vices. Management and counselling therapy for affected girl-child are very vital. Attention should be paid to the boychild before they are totally captured by the owners of baby factory.

iii. Non-Governmental Organisation: The government, media, NGOs as well as the family of a vulnerable child, all can play a very important role in trying to combat these social menaces. The prevention of abduction, trafficking and baby factory must begin at the grass root level by the identification of the supply and demand areas of abduction, trafficking and baby factory, the transit points and routes, which is an extremely difficult task. The best method to prevent trafficking is to integrate it with prosecution and protection. Nongovernmental organisations and international organisations should conduct comprehensive field research to gather more information on destination countries for sold babies through the baby factory. Law should be edict against baby factory. There should also be a campaign that will see to the eradication of gender-based violence against women in Nigeria. The Ministry of Women Affairs aims to support this campaign by raising public awareness on the laws that repudiate violence against women and embarking on the training and sensitization of law enforcement officers on how to effectively protect victims.

\section{Implications for Educational Managers}

i. Strategic plan: Strategic plan on renovations of schools, improved facilities, employment and data base on drop-outs, out of schools should be put in place for follow up. Supervision and inspection of schools to check programmes, availability of human and non - human resources.

ii. Curriculum: Review of curriculum on self-reliance and update to e- curriculum. Introduction of sex education at all levels of education system. Implementation of entrepreneurship skill objectives. Intensify efforts for students' participation. No skill acquisition, no certificate at primary, secondary and tertiary institutions should be enforced.

iii. Capacity building: Awareness creation for the students, parents and teachers during PTA meetings and good parenting. Seminars to create alternative interactive session with the youths. Collaboration with Artisans for industrial attachments. Networking with the security agent, National Agency for Prohibition of Trafficking in Persons (NAPTIP), National Orientation Agency (NOA). Networking with youths on face book, twitter and skype. Catch them young to be a virile citizen in future.

\section{Conclusion}

Wastage of a girl-child is a wastage of a nation. Therefore, educating the girl-child educates the nation. Education will make the girl-child to face the challenges coming from the home (parents), society, peers, abduction, baby factory and summon the challenges so that the girl-child wastage will reduce. If we believe that the girl-child is a nation and that children are the heritage of a nation and asset to human development we need to come to their rescue.

\section{Recommendations}

Enact stringent law against the penetrators and engage reputable law firms to handle "baby factories" cases on a pro 
bono basis.

Security measures should be intensified at the boarders.

National Agency for Prohibition of Trafficking in Persons (NAPTIP) should intensify efforts to curb the sister of child trafficking called baby factory.

To bring awareness to "baby factories" phenomenon and its dangers among people who are more likely to become victims of this type of human trafficking;

To give technical training for the law enforcement agencies, lawyers and judges about "baby factories" and its correlation with human trafficking;

To re-examine programs addressing poverty and illiteracy in sub - African countries most importantly Nigeria in order to identify their main challenges in fighting these major causes of human trafficking and to adjust these programs accordingly. All hands must be on deck to address these challenges before it becomes a canker worn eaten up our youths the leaders of tomorrow. International attention should be paid to the boy-child to safeguard them from these social menaces most importantly baby harvesting so as not to spread virus diseases such as EBOLA, HIV among others.

\section{References}

Adebayo, F. A. (2006). Born free but in chains. Lagos: New Haven Publishers. ISBN 978-8127-27-4.

Adebayo, F. A. (2012). Early childhood education in Nigeria: Implications for educational managers. London International Conference on Education. London, United Kingdom.

Adelakun, Abimbola (2013). The Punch Newspaper, Lagos.

Agence France Presse (2013). Nigeria frees 16 pregnant women from horrifying 'Baby factory'. Huffingtonpost.com. Retrieved 15/04/2014.

Akinkuotu, Eniola (2014). The Punch Newspaper, Lagos.

Akpan, N. S. (2010). Kidnapping in Nigeria's niger delta: An exploratory study. Journal of Social Science. 24(1).

Akpan, N. S. \& Akpabio, E. M. (2009). Oil and conflicts in the niger delta region, Nigeria: Facing the facts. Journal of Social Development in Africa. 24(1): 9-35.

Anyawu, D. K. (2013). Wastage among secondary schools students in Ekiti State. A seminar paper presented at Ekiti State University, Ado-Ekiti.

Delap, Emily (2009). Begging for change: Research findings and recommendation of forced child begging in Albania, Greece, India and Senegal. Anti-Slavery International. Retrieved 10/10/2013.

Fasola, B. R. (2014). Adolescent pregnancy rooted in poverty, gender inequality. Lagos State Government. Retrieved 21/02/2014.

Federal Ministry of Women Affairs (2014). Baby factory in Nigeria. Abuja.

International Labour Congress (ILO) (2014). Inauguration of Boko Haram victim attack fund in Nigeria. www.channeltv.com. Retrieved 15/06/2014.

Kunze, Erin I. (2010). Sex trafficking via the internet: How international agreement address the problem and fail to go far enough. Journal of High Technology Law. 241-289. Retrieved 01/05/2014.

Madukovich, B. (2014). Wordpress.com Retrieved 06/06/2014

The Editorial (2013). The Nation newspaper. Lagos.

UNICEF (2006). The state of the World's Children: Excluded and invisible. Retrieved 18/06/2014

United Nations (2000). optional protocol on the sale of children, child prostitution and child pornography. Retrieved $18 / 06 / 2014$.

Wikipedia (2014): Child harvesting. Retrieved 05/05/2014.

World Bank (2009): Social development note: Conflict, crime and violence. www.worldbank.org. Retrieved 10/10/2013.

Note: Sources of Photographs: Press and Website and personal contact. 